University of Nebraska - Lincoln

DigitalCommons@University of Nebraska - Lincoln

1997

\title{
Attributes of Black-Tailed Prairie Dog Colonies in Northcentral Montana
}

Richard Reading

Denver Zoological Foundation and Northern Rockies Conservation Cooperative, 2900 E. 23rd Avenue, Denver, CO

Randy Matchett

Charles M. Russell National Wildlife Refuge, U.S. Fish and Wildlife Service

Follow this and additional works at: https://digitalcommons.unl.edu/usfwspubs

Part of the Aquaculture and Fisheries Commons

Reading, Richard and Matchett, Randy, "Attributes of Black-Tailed Prairie Dog Colonies in Northcentral Montana" (1997). US Fish \& Wildlife Publications. 20.

https://digitalcommons.unl.edu/usfwspubs/20

This Article is brought to you for free and open access by the US Fish \& Wildlife Service at DigitalCommons@University of Nebraska - Lincoln. It has been accepted for inclusion in US Fish \& Wildlife Publications by an authorized administrator of DigitalCommons@University of Nebraska - Lincoln. 


\section{ATTRIBUTES OF BLACK-TAILED PRAIRIE DOG COLONIES IN NORTHCENTRAL MONTANA}

RICHARD P. READING, Denver Zoological Foundation and Northern Rockies Conservation Cooperative, 2900 E. 23rd Avenue, Denver, CO 80205, USA

RANDY MATCHETT, Charles M. Russell National Wildlife Refuge, U.S. Fish and Wildlife Service, P.O. Box 110, Lewistown, MT 59457, USA

Abstract: We examined several characteristics of black-tailed prairie dog (Cynomys ludovicianus) colonies in Phillips County, Montana, including slope, aspect, soils, land tenure, and distance from roads using a geographic information system (GIS). Colonies exhibited significantly smaller slopes, but not significantly different aspects than did randomly located polygons. In addition, colonies were more prevalent than expected on well drained clay-loam and loam soils and on U.S. Bureau of Land Management (BLM) land than on other soil types or on private land. Although prairie dogs commonly use roads for dispersal, distance to nearest road was not related to prairie dog density nor to colony area. These findings could be used to develop a cartographic model of preferred black-tailed prairie dog habitat useful for prairie dog monitoring and management, and for estimating prairie dog expansion potential for possible black-footed ferret (Mustela nigripes) reintroduction sites.

J. WILDL. MANAGE. 61(3):664-673

Key words: black-footed ferrets, black-tailed prairie dog, colony, Cynomys ludovicianus, Geographic Information System, GIS, modeling, Montana, Mustela nigripes.

Black-tailed prairie dogs live in complexes of colonies that form a mosaic of on- and off-colony habitats referred to as the prairie dog ecosystem (Hoogland 1981, Detling and Whicker 1988, Whicker and Detling 1988, Clark et al. 1989). Researchers have noted generalizations about prairie dog colonies. Several colony characteristics, including slope, aspect, and soil types, presumably reflect prairie dog preference. Researchers state that prairie dog colonies commonly are located on level land (Koford 1958, Tilestone and Lechleitner 1966, Knowles 1982), because steep terrain obstructs their view of predators (King 1955, Hoogland 1979, 1981; Hoogland et al. 1988). In addition, larger colonies may have greater slopes than smaller colonies because as colonies expand they may spread into sub-optimal habitat with steeper slopes (Koford 1958). Researchers have suggested that colonies in northern latitudes are located more commonly on southerly aspects because such exposure favors grasses, as opposed to woody vegetation (Koford 1958). Prairie dogs also may actively select terrain with a southerly aspect to gain the warmth of the winter sun. Finally, because prairie dogs are semifossorial rodents, they require soils that can support their complex burrow systems without collapsing or flooding (Osborn 1942, Koford 1958). However, most of these suppositions have never been quantified (King 1955, Koford 1958; Knowles 1982, 1985). 
Several generalizations of prairie dog colonies were used to develop a habitat suitability index model for black-tailed prairie dogs (Clippinger 1989) and were incorporated into a GIS model of potential and preferred prairie dog habitat (B. Tepley, F. D'Erchia, and T. Schultz, unpubl. data). Although these models may prove useful, the variables on which they were based remain untested. In addition, other colony characteristics, such as land tenure and proximity to roads, have never been examined.

Others colony features analyzed are based on human management and disturbance. Because prairie dogs use roads for dispersal (Knowles $1985,1986 a$ ), and prairie dog shooters use roads to access colonies, the "active" burrow density of colonies with respect to proximity to roads was analyzed. Although total burrow density is often a poor indicator of prairie dog density (King 1955, Houston et al. 1986, Menkens et al. 1989), the density of frequently used, or active, burrows has been correlated to prairie dog density (Biggins et al. 1993). Prairie dog shooting has become increasingly popular in the study site during recent years (U.S. Bur. Land Manage. 1992). Because shooters access colonies by and remain near existing roads (U.S. Bur. Land Manage., unpubl. data), high mortality due to shooting may reduce population densities on colonies near roads.

Colonies also were analyzed with respect to land tenure, because management techniques vary among land owners. Private land owners often are antagonistic toward prairie dogs (Reading and Kellert 1993), and actively may seek to eliminate them. Livestock producers who leased grazing privileges from the state were required to control prairie dogs as a condition of that lease. Compared to private or state lands, control operations on federally administered lands are more difficult to implement (Schroeder 1989). Because federal agencies are mandated to conserve black-footed ferrets under the Endangered Species Act (ESA; Bean 1983), little prairie dog control has taken place on these lands in recent years.

Several people assisted this study. We thank K. Brooks, J. Carlson, D. Christopherson, R. Crete, A. Dood, C. Erb, J. Grensten, B. Haglan, L. Hanebury, D. Hinckley, K. Jewell, B. Miller, G. Miller, S. Minta, J. O'Connell, R. Richardson, and the ranchers from south Phillips County. We thank S. Beissinger, T. Clark, J. Grensten, B. Haglan, S. Kellert, R. Matchett, B. Miller, and J. Wargo for comments on the manuscript N. Bourg and W. Childress assisted with field data collection. Funding was provided by the National Fish and Wildlife Foundation, the Montana Bureau of Land Management, the Montana Department of Fish, Wildlife, and Parks, the Chicago Zoological Society, the U.S Fish and Wildlife Service, the Northern Rockies Conservation Cooperative, and the World Society for the Protection of Animals.

\section{STUDY AREA}

Our study was conducted in southern Phillips County, located in northcentral Montana. Land tenure was a mixture of private, state, and federal. The southernmost portion of the county included a portion of the Charles M. Russell National Wildlife Refuge (CMR). Topography varied from flat upland plains and rolling hills to badlands, rough breaks, and mountains. Elevation varied from 750 to $1,650 \mathrm{~m}$. Soils were derived from glacial till, sedimentary bedrock, and alluvium from mixed rock sources, resulting in complex and diverse soil patterns (U.S. Bur. Land Manage. 1982). Climate was continental with mean annual precipitation of $280-330 \mathrm{~mm}$ and temperature of $-40-38 \mathrm{C}$ (Clark et al. 1987).

Grasslands typical of the Northern Great Plains dominated the area, but sagebrush ( $\mathrm{Ar}$ temisia spp.) and greasewood (Sarcobatus vermiculatus) were common. Major grasses included needle-and-thread (Stipa comata), blue grama (Bouteloua gracilis), western wheatgrass (Agropyron smithii), Sandberg bluegrass (Poa sandbergii), and green needlegrass (Stipa viridula). U.S. Census data from 1990 gave a human population density of about 0.4 persons per $\mathrm{km}^{2}$ for the county. Cattle ranching and grain farming represented the major land uses. For a more complete description, see BLM (1982).

\section{METHODS}

The relation between a variety of features of black-tailed prairie dog colonies were tested by comparing their occurrence on and off prairie dog colonies. Colonies were surveyed, mapped, digitized, and included in a MOSS (Map Overlay and Stat. Syst.) GIS. We mapped colonies $(n=222)$ during the summer of 1988 by hand on 7.5 minute U.S. Geologic Survey (USGS) topographic maps using geographic features for reference. For a more complete description of 
surveying and mapping techniques, see Reading et al. (1989). Colonies were digitized and included in a GIS dataset, as well as land tenure and roads. Prairie dog densities were calculated for 103 colonies (J. Carlson, unpubl. data) with methods developed by Biggins et al. (1993). Because the relation between prairie dog density and burrow density was direct (Biggins et al. 1993, J. Carlson, unpubl. data), analyses were performed only on prairie dog density data. Elevation data, in the form of 7.5 minute digital elevation maps, were obtained from this USGS. We obtained soil associations within the study site from the BLM (1977) in paper map form. Definitions and brief descriptions of soil associations are provided in Reading (1993).

For control we generated polygons within the study area, but not overlapping prairie dog colonies. Because we were unable to replicate exactly the creation of 222 polygons of various sizes and shapes (as is true for prairie dog colonies), we generated random polygons in 4 size classes by creating circles around 222 random coordinates. The numbers and sizes of polygons were based on visual inspection of the distribution of prairie dog colonies by size. Colonies were divided into 4 size classes and means of each size class were calculated. The result was 94 "very small" colonies with a mean size of 5.7 ha, 56 "small" colonies with a mean size of 23.5 ha, 37 "large" colonies with a mean size of 55.8 ha, and 35 "very large" colonies with a mean size of 144.9 ha. Identical numbers of equal sized polygons (representing the mean colony size) were created for each size class of control polygons.

We determined average slope, average aspect, and land tenure for each colony and polygon by overlaying colony and polygon maps over slope, aspect, and surface tenure maps using GIS. To assess the influence of roads on prairie dog colonies, colonies and polygons were overlaid on road maps buffered at 10, 250, 500, $750,1,000,1,500$ and $2,000 \mathrm{~m}$. Buffer zone sizes were based on visual analysis of the distribution of the distance of colonies from roads. Due to the unavailability of digitized soil association data, soil association maps were manually overlaid on plots of colonies and polygons. The area of each soil type within each colony or polygon was determined with an electronic planimeter. Soil associations little represented in Phillips County were pooled to facilitate statistical analyses (i.e., increase sample sizes) on the basis of the similarity of their characteristics, especially those characteristics suspected as important to prairie dogs (Osborn 1942, Koford 1958, U.S. Bur. Land Manage. 1977, Reading 1993).

Slope and aspect data were analyzed with 3 sets of data. First, we calculated mean slope and aspect for each colony or polygon using GIS. Second, we tallied the number of colonies or polygons in each of several slope and aspect classes. And third, the area of colonies or polygons in each of several slope and aspect classes was determined.

Colonies were compared against polygons acting as controls for each variable. Comparisons among and between different sized colonies or polygons were made with respect to slope, aspect, land tenure, and soil association distribution. Variables were tested for homogeneity of group variance with Bartlett's test and were examined for normality. Slope data, prairie dog density data, and prairie dog colony area data were natural log normalized to compare means and analyze regressions. We compared mean colony slope and aspects with mean polygon slopes and aspects using analysis of variance (ANOVA) or simple $t$-tests. Tukey's studentized range HSD test was used for pairwise comparisons of all multiple means tested with ANOVAs. The Tukey-Kramer adjustment (harmonic mean adjustment) was performed for comparisons between groups with unequal sample sizes. We compared the number of colonies and polygons in each slope and aspect class using log likelihood ratio tests. We compared mean areas of polygons and colonies within each soil type and land tenure classification using multiple analysis of variance (MANOVA) tests. Data on proximity to roads were analyzed with ANOVA and multiple and linear regression. Means are presented \pm standard errors.

\section{RESULTS \\ Slope and Aspect}

Prairie dog colonies were located on terrain characterized by small slopes (mean $=5.20 \pm$ $1.49 \%)$. Both the area and the number of colonies were strongly skewed toward smaller slopes (Fig. 1). Random polygons also were found mostly on level terrain (mean $=7.07 \pm$ $0.54 \%$ ) and characterized by distributions skewed toward smaller slope classes (Fig. 1). However, the mean percent slope of prairie dog 


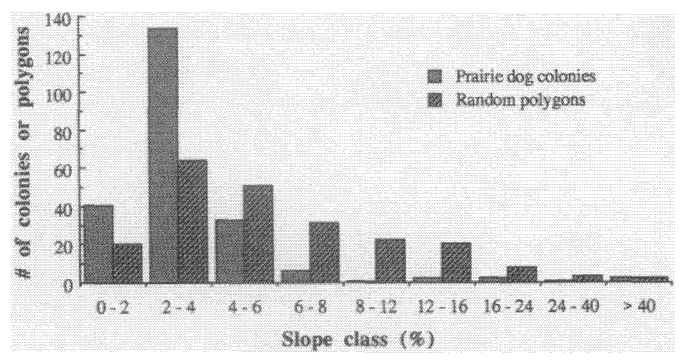

Fig. 1. Number of prairie dog colonies and random polygons in each slope class.

colonies was significantly smaller than the percent slope of polygons (Tables 1 and 2).

Prairie dog colonies were characterized by southerly aspects $\left(\right.$ mean $\left.=172.10 \pm 3.61^{\circ}\right)$; however, polygons displayed a similar southerly aspect $\left(\right.$ mean $\left.=171.52 \pm 3.93^{\circ}\right)$ and did not differ significantly from colonies (Tables 1 and 2). The distribution of aspects for both area and number did not differ between colonies and polygons (Table 1 and 2, Fig. 2). Thus, the southerly aspect of prairie dog colonies in south Phillips County was an artifact of local topography.

Comparisons of mean slope and aspect also were made between colonies and polygons of similar sizes. Results of pairwise colony to polygon comparisons by size were similar to overall comparisons of colonies and polygons (Tables 1 and 2). Mean slopes of very small (mean $=6.84$ $\pm 3.44 \%)$, large (mean $=4.62 \pm 0.99 \%)$, and very large $($ mean $=3.38 \pm 0.38 \%$ ) colonies were significantly smaller than were very small $($ mean $=8.41 \pm 1.13 \%)$, large $($ mean $=6.56 \pm$ $0.73 \%)$, and very large (mean $=6.11 \pm 0.66 \%)$ polygons. Aspects of very small, large, and very large colonies $\left(\right.$ mean $=168.05 \pm 7.09^{\circ}, 167.53$ $\pm 8.00^{\circ}$, and $176.07 \pm 4.83^{\circ}$ ) and polygons $\left(\right.$ mean $=175.09 \pm 6.95^{\circ}, 169.06 \pm 6.75^{\circ}$, and $\left.167.95 \pm 6.49^{\circ}\right)$ did not differ significantly. Comparisons of aspects of small (mean size = $23.5 \mathrm{ha}$ ) colonies to polygons were ambiguous because the results varied depending on the statistical test used. While slope (mean $=3.96 \pm$ $0.99 \%)$ and aspect $\left(\right.$ mean $\left.=179.43 \pm 5.16^{\circ}\right)$ of small colonies did not differ significantly from slope (mean $=5.75 \pm 0.45 \%$ ) and aspect (mean $=169.39 \pm 8.53^{\circ}$ ) of small polygons, slope and aspect distributions by percent acreage and by numbers of polygons or colonies were significantly different (Tables 1 and 2; Reading 1993).

\section{Soils}

Prairie dog colonies and random polygons were distributed over a number of different soil associations (Fig. 3). For a description of the soil associations, see Reading (1993). After pooling similar soil association classes for statistical analyses, colony and polygon distributions differed significantly (Table 3). Comparisons of soil types among different sized colonies and polygons gave similar results. The prevalence of very small (Pillai Trace $=1.21 ; F=13.17 ; 18$, $154 \mathrm{df} ; P<0.001$ ), small (Pillai Trace $=1.51$; $F=17.51 ; 18,102 \mathrm{df} ; P<0.001$ ), large (Pillai Trace $=1.56 ; F=8.26 ; 18,42 \mathrm{df} ; P<0.001$ ), and very large (Pillai Trace $=1.58 ; F=15.10$; $18,72 \mathrm{df} ; P<0.001$ ) colonies and polygons on the various soil associations in the regions differed significantly.

Prairie dog colonies were more prevalent on the clay-loam Elloam soil associations (soil association $13, F=18.44,1 \mathrm{df}, P<0.001$ and 14 , $F=19.74,1 \mathrm{df}, P<0.001)$, the loam-clay loam Ustic Torrifluvents/Torriorthents (soil association $11, F=20.29,1 \mathrm{df}, P<0.001$ ), and other more minor soil associations $(F=11.46,1 \mathrm{df}$, $P<0.01$ ). Colonies were less prevalent on the clay-silty clay Dilts soil associations (soil association $9, F=22.26,1 \mathrm{df}, P<0.001 ; 27, F=$ $5.98,1 \mathrm{df}, P<0.05$; and $29, F=22.32,1 \mathrm{df}$, $P<0.001$ ) (Fig. 3). There was no significant difference in the prevalence of colonies and random polygons on the loamy Phillips (soil associations $15-16, F=0.62,1 \mathrm{df}, P=0.43)$ and

Table 1. Comparisons of the mean slopes and aspects of black-tailed prairie dog colonies and random colonies of different sizes, 2-way ANOVA.

\begin{tabular}{|c|c|c|c|c|c|}
\hline \multirow[b]{2}{*}{ Factors } & \multirow[b]{2}{*}{ df } & \multicolumn{2}{|c|}{ Slope } & \multicolumn{2}{|c|}{ Aspect } \\
\hline & & $F$-ratio & $P$ & $F$-ratio & $P$ \\
\hline Size & 3 & 2.97 & 0.03 & 0.18 & 0.91 \\
\hline Polygon type (colony or random) & 1 & 31.97 & $<0.01$ & 0.17 & 0.68 \\
\hline Interaction (polygon $\times$ size $)$ & 3 & 1.69 & 0.17 & 0.66 & 0.58 \\
\hline Error & 436 & & & & \\
\hline
\end{tabular}


Table 2. Comparisons of the percent area of black-tailed prairie dog colonies and random polygons within different slope and aspect classes. Log likelihood $\chi^{2}$ tests.

\begin{tabular}{|c|c|c|c|c|c|c|}
\hline \multirow[b]{2}{*}{ Factors } & \multicolumn{3}{|c|}{ Slope } & \multicolumn{3}{|c|}{ Aspect } \\
\hline & $\mathrm{df}$ & $x^{2}$ & $P$ & $\mathrm{df}$ & $x^{2}$ & $P$ \\
\hline All & 4 & 47.83 & $<0.01$ & 5 & 4.68 & 0.46 \\
\hline Very small $($ mean $=5.7 \mathrm{ha})$ & 3 & 9.41 & $<0.01$ & 5 & 9.52 & 0.09 \\
\hline Small $($ mean $=23.5 \mathrm{ha})$ & 3 & 40.29 & $<0.01$ & 5 & 23.84 & $<0.01$ \\
\hline Large $($ mean $=55.8 \mathrm{ha})$ & 3 & 38.17 & $<0.01$ & 5 & 5.90 & 0.32 \\
\hline Very large $($ mean $=144.9$ ha $)$ & 3 & 49.76 & $<0.01$ & 4 & 4.46 & 0.35 \\
\hline
\end{tabular}

Kevin (soil association $19, F=0.03,1 \mathrm{df}, P=$ 0.87 ) soil associations than were polygons. Colonies and polygons in different size classes yielded similar results. Prairie dog colonies for all size classes were more prevalent on soil associations 13,14 , and other more minor soil associations and less prevalent on other associations than similar sized random polygons.

The size of the prairie dog colony also was correlated significantly with the soil associations on which the colony was located, as was the interaction between polygon type (i.e., colony or random polygon) and size (Table 3). However, no clear trends were evident from smaller to larger colonies (i.e., prevalence would increase and then decrease for some soil associations and vice versa).

Soil associations could not be compared with the other parameters because the soils data were not digitized for GIS. However, soil types, and particularly soil associations were partially dependent on slopes (U.S. Bur. Land Manage. 1977, 1981). Indeed, slopes are incorporated into most soil association definitions (U.S. Bur. Land Manage. 1977).

\section{Land Tenure}

Tenureship patterns for colonies and random polygons varied considerably (Fig. 4). The dis-

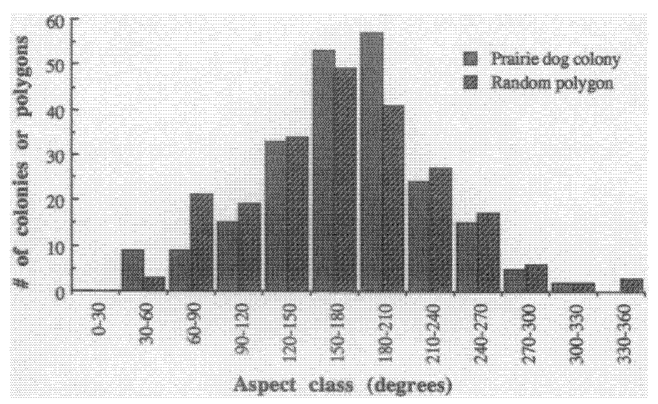

Fig. 2. Number of prairie dog colonies and random polygons in each aspect class. tributions of the percent colony area and the percent polygon area under different ownership differed significantly, as did ownership patterns for colonies of different sizes and the interaction between the type of polygon (i.e., a colony or a random polygon) and its size (Table 3 ). Colonies were more likely to be located on land under BLM ownership ( $F=13.38,1 \mathrm{df}, P<$ 0.001 ) and less likely to be located on private land $(F=37.46,1 \mathrm{df}, P<0.001)$ than were random colonies (Fig. 4). There was no significant difference with respect to ownership by the U.S. Fish and Wildlife Service (FWS; $F=$ $0.78,1 \mathrm{df}, P=0.38$ ), the State of Montana ( $F$ $=2.88, \mathrm{I} \mathrm{df}, P=0.09)$, or other government agencies $(F=3.38,1 \mathrm{df}, P=0.07)$.

Land tenure distributions by size classes differed significantly for very small (Pillai Trace $=$ $0.75 ; F=25.09 ; 10,420 \mathrm{df}, P<0.001$ ), small (Pillai Trace $=1.07 ; F=20.30 ; 10,178 \mathrm{df}, P<$ 0.001 ), large (Pillai Trace $=1.00 ; F=16.53$; $10,176 \mathrm{df} ; P<0.001$ ), and very large (Pillai Trace $=1.15 ; F=17.52 ; 10,130 \mathrm{df} ; P<0.001)$

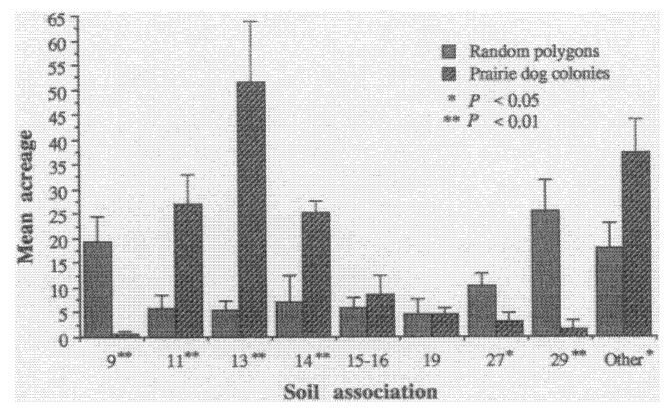

Fig. 3. Mean $( \pm S E)$ acreage of soil associations of prairie dog colonies and random polygons. Soil associations are as follows: 9 = Dilts-Bascovy, $11=$ Ustic Torrifluvents-Ustic Torriorthents, 13 = Elloam-Slickspot, 14 = Elloam-Thoeny, $15=$ Phillips-Elloam, 16 = Phillips-Theony, $19=$ Kevin-Phillips, 27 = Sunburst-Dilts, 29 = Elloam Dilts, and other = cultivated land, rock outcrops, shales, and Creed-Tealer, Vaeda, Marvan-Vaeda, Bascovy-Dits associations. See U.S. Bur. Land Manage. (1977) and Reading (1993) for a description of the soil associations. 
Table 3. Comparisons of the soils and land tenure of black-tailed prairie dog colonies and random colonies of different sizes. 2-way MANOVA Pillai Trace (P.T.) test.

\begin{tabular}{|c|c|c|c|c|c|c|}
\hline \multirow[b]{2}{*}{ Factors } & \multicolumn{3}{|c|}{ Soils } & \multicolumn{3}{|c|}{ Land tenure } \\
\hline & $\mathrm{df}$ & 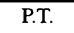 & $F$-stat. & $\mathrm{df}$ & 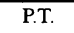 & $F$-stat. \\
\hline Size & 27,621 & 0.95 & $10.72 *$ & 15,1386 & 0.90 & $39.52 *$ \\
\hline Polygon type (colony or random) & 9,205 & 0.56 & $28.90^{*}$ & 5,460 & 0.09 & $9.29 *$ \\
\hline Interaction (polygon $\times$ size $)$ & 27,621 & 0.69 & $6.90 *$ & 15,1386 & 0.14 & $4.64 *$ \\
\hline
\end{tabular}

$* P<0.01$

colonies and polygons. A small proportion of the total area of very large colonies was located on private land $(14.23 \%)$ compared with smaller colonies (32.24-38.75\%) and random polygons (39.34-46.04\%). Alternatively, a large proportion of very large colonies was located on BLM land $(60.87 \%)$ compared with smaller colonies $(34.30-47.49 \%)$ and random polygons (30.89$41.49 \%$ ). No other trends were evident from smaller to larger colonies.

Prairie dog densities did not differ significantly among colonies under different ownership $(F=1.25,3 \mathrm{df}, P=0.30)$. Prairie $\operatorname{dog}$ colonies on private land had the highest density (mean $=30.34 \pm 1.96$ prairie dogs/ha) and colonies on BLM had the lowest (mean $=24.93$ \pm 0.90 prairie $\mathrm{dogs} / \mathrm{ha}$ ), with prairie densities on state lands (mean $=25.58 \pm 1.98$ prairie dogs/ha) and FWS lands (mean $=27.71 \pm 1.82$ prairie dogs/ha) falling between the two. There were no significant differences for pairwise comparisons of prairie dog densities among colonies under different ownership.

Because both slope and land tenure distributions of prairie dog colonies were significantly different from random polygons, the slopes of land under different ownership were compared. Differences in land tenure distributions between colonies and polygons could be attributable simply to differences in the average slopes of land under different ownership. Slopes did differ significantly among landowners $(F=8.28$,

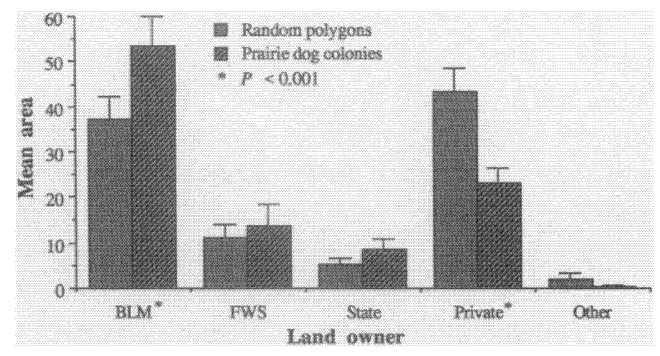

Fig. 4. Mean ( $\pm S E$ ) area of land tenure on prairie dog colonies and random polygons.
$3 \mathrm{df}, P<0.001)$. The BLM administers land with the smallest slope $($ mean $=4.52 \pm 0.24 \%)$ of any landowner in south Phillips County, significantly smaller than the slopes of land under the administration of either the FWS (mean = $10.42 \pm 0.71 \%)$ or the State of Montana and other minor land holders (i.e., the U.S. Bur. Reclamation, the Army Corps of Engineers; Tukey's HSD Test $P<0.05)$. The latter had the largest slope $($ mean $=11.02 \pm 2.53 \%)$. There were no significant differences between slope comparisons of the BLM and private land (mean $=6.93 \pm 1.57 \%)$, and other pairwise combinations of landowners (Tukey's HSD Test at $\mathrm{P}<0.05$ ).

The distributions of both the number of polygons (count data) $\left(\chi^{2}=70.76,4 \mathrm{df}, P<0.001\right)$ and the area of polygons in each slope class $\left(\chi^{2}\right.$ $=211.67,4 \mathrm{df}, P<0.001$; Fig. 5) were also significantly different. However, in contrast to comparisons with mean slopes, almost all pairwise comparisons between different land owners with slope distributions were significant $\mathrm{Ta}$ ble 4). The only insignificant tests were comparisons between distributions of the number of polygons on BLM land with the number of polygons on private land, and between the number of polygons on FWS land with the the number of polygons on State of Montana and other land.

These discrepant results make it difficult to assess whether or not both land tenure and

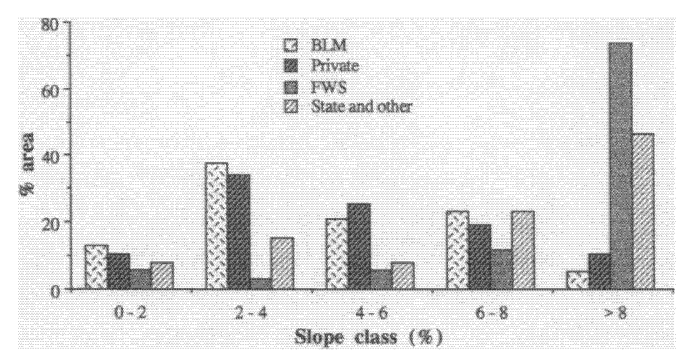

Fig. 5. Percent area of random polygons under different ownership by slope class. 
Table 4. Comparison of the number of colonies in different slope classes by land tenure with the log likelihood ratio test. Comparisons of all groups were significantly different $\left(\chi^{2}=\right.$ 66.99, $P<0.001$ ).

\begin{tabular}{lccc}
\hline & \multicolumn{3}{c}{ Likelihood ratio $\chi^{2}$ scores } \\
\cline { 2 - 4 } \multicolumn{1}{c}{ Owner } & BLM & FWS & Private \\
\hline FWS & $60.61^{* *}$ & & \\
Private & 1.92 & $39.65^{* *}$ & \\
State and other & $13.68^{* *}$ & $0.16 \dagger$ & $7.49^{*}$ \\
\hline
\end{tabular}

$* P<0.05$

$* * P<0.01$

+ Test suspect due to small sample size.

slopes differed significantly between colonies and polygons, or whether one variable was significant only because it was correlated with the other. However, the slopes of BLM and private landowners were the most similar (Table 4 and Fig. 5), while earlier comparisons of prairie dog colonies by land tenure found the greatest discrepancies between the BLM and private landowners (Fig. 4). These findings suggests that slope and land tenure are at least partially independent variables. More importantly, they are more useful as predictors of colony location together than each would be alone.

\section{Distance to Roads}

A black-tailed prairie dog colony's proximity to roads was not significantly correlated with either prairie dog density ( $\ln$ [prairie dog density] $=3.193+\left[3.28 \times 10^{-5}\right] \times$ distance to road, $R^{2}$ $=0.009, F=0.647, P=0.424)$ nor prairie $\operatorname{dog}$ colony area $(\ln [$ colony area $]=3.803+[1.72 \times$ $\left.10^{-4}\right] \times$ distance to road, $R^{2}=0.017, F=1.272$, $P=0.263)$. Prairie dog density was not significantly related to colony area $(F=2.396,1 \mathrm{df}$, $P=0.125)$, nor to the interaction between colony area and distance to nearest road $(F=$ $0.631,3 \mathrm{df}, P=0.587)$. Finally, the distance of a colony to the nearest road did not differ with respect to land tenure $(F=0.842,3 \mathrm{df}, P=$ 0.474).

\section{DISCUSSION}

\section{Slope and Aspect}

Many researchers have noted that prairie dog colonies commonly are found on relatively level terrain (Koford 1958, Tilestone and Lechleitner 1966, Knowles 1982, Menkens et al. 1989, Clippinger 1989), and steep slopes have been cited as effective barriers to prairie dog expansion (Koford 1958, Knowles 1982). Level terrain facilitates predator detection, and has been the most commonly cited explanation for the prevalence of colonies on small slopes (King 1955, Hoogland 1979, 1981; Cable and Timm 1988, Hoogland et al. 1988). However, the steeply sloped areas of south Phillips County are highly erodible (U.S. Bur. Land Manage. 1977), and could provide an additional disincentive to colonization by prairie dog. Therefore, it was not surprising to find that colonies occupied significantly smaller slopes than random polygons.

Some researchers suggest that prairie dogs also avoid extremely flat land to escape flooding (Koford 1958). Optimal slopes are suggested as ranging between 2 and 5\% (Koford 1958). In this study the slopes of most colonies and most colony area ranged between 2 and $4 \%$ (Fig. 1). However, the lack of colonies on flatter land probably reflects the relative scarcity of flat terrain, not avoidance of level areas, by prairie dogs. Indeed, there were more colonies and a higher percentage of colony area on land with $0-2 \%$ slopes than there were polygons or polygon area.

Southerly aspects receive greater incident solar radiation in the Northern Hemisphere. Grasses often dominate southerly aspects, while woody vegetation is common on northerly aspects and it has been suggested that this vegetation pattern influences prairie dog distributions in northern latitudes (Koford 1958). In addition, because of the harsh northcentral Montana winters, prairie dogs might prefer southerly aspects because they receive added warmth. However, extremely hot summers might influence prairie dogs to select cooler, northerly aspects. Although black-tailed prairie dogs do not hibernate and spend most of their waking hours aboveground (King 1955, Smith 1958, Hoogland 1979), the relatively constant environment of prairie dog burrows provides relief from both summer heat and winter cold (Henderson et al. 1974). Although colonies in south Phillips County exhibited predominantly southern aspects, this southern exposure appeared to be an artifact local terrain, rather than selection by prairie dogs. South Phillips County slopes south, draining into the Missouri River along the southern boundary of the county and study site.

\section{Soils}

Few researchers have described the soils of black-tailed prairie dog colonies. It has been suggested that prairie dogs prefer fine sandy 
loams and that very sandy soils are not favorable to prairie dogs, but that soils types appear to have little influence on prairie dog distributions (Osborn 1942). An examination of the soils of 28 black-tailed prairie dog colonies in North Dakota found most colonies on fine to medium textured alluvial soils (Reid 1954 in Koford 1958). Half of the colonies were on clay loam soils and several more were on silt loams. Similarly, another study found most colonies on deep alluvial soils of medium to fine texture; however, colonies were also found on several other soil types and prairie dogs were found capable of burrowing in most soils (Koford 1958). The results of this study suggested that the most important aspects of soils are their moisture capacity and texture, factors influencing the growth of vegetation preferred by prairie dogs (Koford 1958). A third researcher suggested that prairie dog prefer clay soils (Clippinger 1989).

Our study supports the contentions of earlier researchers. Prairie dog colonies were more prevalent on Elloam and Ustic-Torrifluvents/ Torriorthents dominated soil associations (no. 11,13 and 14) and less prevalent than expected on most other associations, especially soil associations with Dilts soils and large slopes (no. 9, 27, and 29; see Reading 1993). A comparison of Elloam, Ustic-Torrifluvents/Torriorthents and Dilts soils explains this preference (U.S. Bur. Land Manage. 1981, Reading 1993). Elloams and Ustic-Torrifluvents/Torriorthents are deep, well-drained sandy loam-to-clay loam soils with high water capacity. Alternatively, Dilts are shallow, well-drained clay-to-silty clay soils with very low water capacity. Elloam soils therefore provide more favorable depth and structural support for the construction of prairie dog burrow systems and, being well-drained, are less likely to flood.

The significance of colony size in relation to soil association is not easily explained, as no clear trends were evident. The relation of colony size to soil association could simply be a problem of inadequate sample sizes for this level of analysis.

\section{Land Tenure}

Given the antagonism of local ranchers toward prairie dogs (Reading and Kellert 1993), significant differences in colony location with respect to land tenure were to be expected. Colonies, especially very large colonies, were more common on BLM land and less common on private land than were polygons. Federal wildlife and land management agencies, such as the BLM, are mandated to conserve threatened and endangered species under Section 7(a) of the ESA (Bean 1983). State agencies are constrained by similar state legislation. Because the critically endangered black-footed ferret requires prairie dogs for survival, these acts mandate prairie dog conservation. State regulations require leasees of Montana state lands to eliminate prairie dogs from leased land, but enforcement of that requirement recently has been relaxed.

Possibly, the prevalence of colonies on BLM land and the absence of colonies on private land could be an artifact of the type of land the BLM and private interests own. For example, western land tenure patterns are usually characterized by private ownership of bottom lands containing streams, rivers, and creeks (to control water resources; Culhane 1981); the relatively flat uplands are under federal ownership. There is probably greater pressure to control prairie dogs on the more fertile bottom lands used for crop and hay production than on upland grazing lands. Slope class distribution comparisons were less clear and not easily explained.

The FWS manages the CMR in the southernmost portion of Phillips County. This land is part of the Missouri breaks and is characterized by rough, steep slopes with highly erodible soils gradating into rolling prairie (U.S. Bur. Land Manage. 1982, Knowles 1986b). Much of this land therefore is not suitable to prairie dog colonization.

\section{Distance to Roads}

Prairie dog colony density and colony area were not related to the distance of the colony from the nearest road, despite the fact that prairie dogs use roads for dispersal and prairie dog shooters use roads to access colonies (Knowles 1985, 1986a; U.S. Bur. Land Manage. 1982, 1992 , pers. obs.). Of course, these 2 opposing forces (increased dispersal and increased mortality) could negate each other. However, roads in south Phillips County varied from paved to gravel to improved dirt to simple 2-track trails, but road type was not differentiated in GIS. While prairie dogs make use of all of these roads for dispersal (Knowles 1985, 1986b,), it is likely that shooting pressure is more intense on the higher quality roads because the roads pro- 
vide greater access to motorized vehicles. Other important considerations for prairie dog shooting pressure include the proximity of other colonies (because shooters are more likely to visit areas with high concentrations of colonies) and the distance of colonies from both highways and towns.

\section{MANAGEMENT IMPLICATIONS}

The results from this study could be used to develop a cartographic model of preferred black-tailed prairie dog habitat. To increase the model's use in Phillips County, soil associations should be digitized. In addition, correlations between prairie dog colonies and vegetation require additional research. Short vegetation has been suggested as encouraging prairie dog expansion (King 1955), whereas research has demonstrated that tall vegetation, often promoted by reduced grazing pressure, inhibits colony expansion (Snell and Hlavachick 1980, Knowles 1982, Uresk et al. 1982, Snell 1985, Cable and Timm 1988, Knowles 1988). If significant, a vegetation variable should be incorporated into any cartographic model developed to improve predictive powers. Such a model could be used to facilitate black-tailed prairie dog management and to assess areas for prairie dog colonization or expansion. By predicting where future prairie dog expansion is most likely to occur, managers could more effectively and efficiently monitor or control prairie dogs. More importantly, the model could be used to assess potential black-footed ferret reintroduction sites by estimating prairie dog expansion potential. Black-footed ferrets are endangered mustelids that feed on prairie dogs and depend on their burrows for shelter, therefore understanding prairie dog colony dynamics is crucial for successful recovery of ferrets.

Black-tailed prairie dog colonies were examined with respect to colony density, visibility into surrounding vegetation, distance of suitable sites to colony edges, and percent forb cover, and population density and visibility were significant, permitting development of a simple model (Cincotta et al. 1988). These results suggest that future studies should include prairie dog density and visibility into surrounding vegetation in GIS models.

A study of the effects of prairie dog shooting on prairie dog social ecology and colony dynamics is needed. Heavy shooting has been suggested as significantly reducing reproduction by disrupting the prairie dog social system (Stockrahm 1979). One study found that moderate shooting pressure could significantly reduce prairie dog densities and prevent expansion, especially on smaller colonies (Knowles 1988). The effects of prairie dog shooters in south Phillips County may be significant. Hundreds of recreationists visit the area each year to spend several days shooting prairie dogs (U.S. Bur. Land Manage. 1982, 1992). Other considerations that require further research include the relation between prairie dog colony expansion and the proximity of other colonies (Garret and Franklin 1982, Knowles 1985, Cincotta et al. 1988) and the association of prairie dog colonies with areas of heavy livestock use (i.e., stock ponds; Knowles 1986b).

\section{LITERATURE CITED}

BEAN, M. J. 1983. The evolution of national wildlife law. Praeger Publ., New York, N.Y. 449pp.

Biggins, D., B. Miller, L. Hanebury, B. OAKleaf, A. Farmer, R. CRete, AND A. Dood. 1993. A system for evaluating black-footed ferret habitat. Pages 73-92 in J. Oldemeyer, D. Biggins, B. Miller, and R. Crete, eds. Management of prairie dog complexes for black-footed ferret reintroduction. U.S. Fish and Wildl. Serv. Biol. Rep. 13.

Cable, K. A., AND R. N. TIMm. 1988. Efficacy of deferred grazing in reducing prairie dog reinfestation rates. Pages 46-49 in Proc. Eighth Great Plains Wildl. Damage Control Workshop. U.S. For. Serv. Gen. Tech. Rep. RM-154.

Cincotta, R. P., D. W. URESK, and R. M Hansen. 1988. A statistical model of expansion in a colony of black-tailed prairie dogs. Pages 30-33 in Proc. Eighth Great Plains Wildl. Damage Control Workshop. U.S. For. Serv. Gen. Tech. Rep. RM-154.

Clark, T. W., J. Grensten, M. Gorges, R. Crete, AND J. GILL. 1987. Analysis of black-footed ferret translocation sites in Montana. Prairie Nat. 19 43-56.

- D. HINCKLEY, AND T. RICH, EDITORS. 1989. The prairie dog ecosystem: managing for biological diversity. Montana BLM Wildl. Tech. Bull. 2. $55 \mathrm{pp}$.

Clippinger, N. W. 1989. Habitat suitability index models: Black-tailed prairie dog. U.S. Fish and Wildl. Serv. Biol. Rep. 82. 21pp.

Culhane, P. J. 1981. Public lands politics: interest group influence on the Forest Service and the Bureau of Land Management. John Hopkins Univ. Press, Baltimore, Md. 398pp.

Detling, J. K., AND A. D. Whicker. 1988. Control of ecosystem processes by prairie dogs and other grassland herbivores. Pages 23-29 in Proc. Eighth Great Plains Wildl. Damage Control Workshop. U.S. For. Serv. Gen. Tech. Rep. RM-154.

Garret, M. G., and W. L. Franklin. 1982. Prairie 
dog dispersal in Wind Cave National Park: possibilities for control. Pages 185-198 in R. M. Timm and R. J. Johnson, eds. Proc. Fifth Great Plains Wildl. Damage Control Workshop. Inst. Agric. and Nat. Res., Univ. Nebraska, Lincoln.

HENDERSON, F. R., P. F. SPRINGER, AND R. ADRIAN 1979. The black-footed ferret in South Dakota. S. Dakota Dep. Game, Fish, and Parks Tech. Bull. 4:1-37.

Hoogland, J. L. 1979. The effect of colony size on individual alertness of prairie dogs (Sciuridae: Cynomys spp.). Anim. Behav. 27:384-407.

1981. The evolution of coloniality in whitetailed and black-tailed prairie dogs (Sciuridae: Cynomys leucurus and C. ludovicianus). Ecology 62:252-272.

- D. K. ANGell, J. G. Daley, AND M. C. RaDCLIFFE. 1988. Demography and population dynamics of prairie dogs. Pages 18-22 in Proc. Eighth Great Plains Wildl. Damage Control Workshop. U.S. For. Serv. Gen. Tech. Rep. RM-154.

Houston, B. R., T. W. Clark, and S. C. Minta. 1986. Habitat suitability index model for the black-footed ferret: a method to locate transplant sites. Great Basin Nat. Mem. 8:99-114.

KING, J. A. 1955. Social behavior, social organization, and population dynamics in a black-tailed prairie dog town in the Black Hills of South Dakota Contrib. Lab. Vert. Biol. Univ. Michigan 65 . $123 \mathrm{pp}$

KNOWLES, C. J. 1982. Habitat affinity, populations, and control of black-tailed prairie dogs on the Charles M. Russell National Wildlife Refuge. Ph.D. Thesis, Univ. Montana, Missoula. 171pp.

- 1985. Observations on prairie dog dispersal in Montana. Prairie Nat. 17:33-40.

1986a. Population recovery of black-tailed prairie dogs following control with zinc phosphide. J. Range Manage. 39:249-251.

$986 \mathrm{~b}$. Some relationships of black-tailed prairie dogs to livestock grazing. Great Basin Nat. 46:198-203

- 1988. An evaluation of shooting and habitat alteration for control of black-tailed prairie dogs. Pages 53-56 in Proc. Eighth Great Plains Wildl. Damage Control Workshop. U.S. For. Serv. Gen. Tech. Rep. RM-154.

KofORD, C. B. 1958. Prairie dogs, whitefaces, and blue grama. Wildl. Monogr. 3. 78pp.

Menkens, G. E., JR., B. J. Miller, and S. H. ANDERSON. 1989. White-tailed prairie dog ecology in Wyoming. Pages 34-38 in Proc. Eighth Great Plains Wildl. Damage Control Workshop. U.S. For. Serv. Gen. Tech. Rep. RM-154.

OSBORN, B. 1942. Prairie dogs in shinnery (oak scrub) savannah. Ecology 23:110-115.

READING, R. P. 1993. Toward an endangered species reintroduction paradigm: a case study of the black-footed ferret. Ph.D. Thesis, Yale Univ., New Haven, Conn. 535pp.
a proposed black-footed ferret (Mustela nigripes) reintroduction. Conserv. Biol. 7:569-580.

- , J. J. Grensten, S. R. Beissinger, AND T. W. CLARK. 1989. Attributes of black-tailed prairie dog (Cynomys ludovicianus) colonies in northcentral Montana, with management recommendations for the conservation of biodiversity. Montana BLM Wildl. Tech. Bull. 2:13-27.

REID, N. J. 1954. The distribution of the black-tailed prairie dog in the badlands of southwestern North Dakota. M.S. Thesis, Iowa State Univ., Ames. 30pp.

SCHROEDER, M. 1989. Endangered species consideration in prairie dog management. Pages 123124 in Proc. Eighth Great Plains Wildl. Damage Control Workshop. U.S. For. Serv. Gen. Tech. Rep. RM-154.

SMITH, R. E. 1958. Natural history of the prairie dog in Kansas. Univ. Kans. Nat. Hist. and State Biol. Survey of Kans. Misc. Publ. 49:1-36.

SNELL, G. P. 1985. Results of control of prairie dogs. Rangelands 7:30.

- AND B. D. Hlavachick. 1980. Control of prairie dog-the easy way. Rangelands 2:239 240.

Stockrahm, D. M. R. B. 1979. Comparison of population structure of black-tailed prairie dog towns in southwestern North Dakota. M.S. Thesis, Univ. North Dakota, Grand Forks. 103pp.

Tileston, J. V., AND R. R. Lechleitner. 1966 Some comparisons of the black-tailed and white-tailed prairie dogs in north-central Colorado. Am. Midl. Nat. 75:292-316.

Uresk, D. W., J. G. MaCracken, and A. J. BJugSTAD. 1982. Prairie dog density and cattle grazing relationships. Pages 199-201 in R. M. Timm and R. J. Johnson, eds. Proc. Fifth Great Plains Wildl. Damage Control Workshop. Inst. Agr. and Nat. Res. Univ. Nebraska, Lincoln.

U.S. BUREAU OF LAND MANAGEMENT. 1977. Soil survey field legend, reconnaissance soil survey: Bureau of Land Management administered lands. Montana BLM, Phillips Resour. Area, Malta. $37 \mathrm{pp}$.

1981. Prairie pothole draft environmental impact statement: vegetation allocation. II. Appendices. Montana BLM, Billings. 223pp.

1982. Black-tailed prairie dog control/management in Phillips Resour. Area. Montana BLM, Malta. 40pp.

- 1992. Final Judith-Valley-Phillips resource management plan and environmental impact statement. Montana BLM, Billings. 750pp.

WhiCKER, A. D., AND J. K. DETLING. 1988. Ecological consequences of prairie dog disturbances. BioScience 38:778-785.

\section{Received 28 June 1995}

Accepted 19 November 1996

Associate Editor: McDonald. 